\title{
Mobile Devices in Technical and Engineering Education with Focus on ESP
}

\author{
http://dx.doi.org/10.3991/ijim.v10i2.5466 \\ Ivana Simonova \\ University of Hradec Kralove, Hradec Kralove, Czech Republic
}

\begin{abstract}
Mobile devices have become widely accepted and exploited didactic means on all levels of education and in all subjects to appropriate extent, including foreign languages. This study focuses on their use within technical (i.e. bachelor) and engineering (i.e. master) higher education in Informatics and Management study programmes at the Faculty of Informatics and Management (FIM), University of Hradec Kralove (UHK), Czech Republic, particularly focusing on comparison of general subjects to English for specific purposes (ESP). Therefore, following questions were set to be researched: (1) What types of mobile devices do students possess?, (2) What purposes do students use mobile devices? and (3) What is students' feedback after mobile devices implementation in ESP and other subjects is? The case study was exploited to describe the state in mobile-assisted language learning (MALL) at FIM and students' feedback was collected by the questionnaire on this approach to teaching/learning. The results show Czech students are sufficiently equipped by mobile devices so that these can be implemented in the process of teaching/learning of all subjects, including ESP.
\end{abstract}

Index Terms-Mobile-assisted language learning, MALL, m-learning, English for specific purposes, ESP, higher education, engineering education.

\section{INTRODUCTION}

A shift has been detected within the exploitation of didactic means reflecting the latest technical and technological development, i.e. from traditional, non-portable (immobile) devices to mobile ones. Mobile devices have become standard on all levels of education and in all subjects, including foreign languages. Until now the traditional e-learning using non-portable devices has been widely implemented into the education in the Czech Republic. This state reflected the fact mobile devices were not widely available for reasonable prices on the Czech market. Within last two-three years the situation changed substantially and currently the mobile learning has been step-by-step moving from small-scale, short-term trials to larger, more sustained and blended deployment. Foreign languages can be even understand as a leader in the field of mobile-assisted language learning (MALL). This process started from unintentional listening to songs, mostly in English, to highly intentional learning activities, e.g. listening to texts, speaking - communicating, either separately, or within various mobile applications or a learning management system (LMS) running on mobile devices [1].

This study focuses on the use of mobile devices within technical (i.e. bachelor) and engineering (i.e. master) higher education in Informatics and Management study programmes at the Faculty of Informatics and Management (FIM), University of Hradec Kralove (UHK), Czech Republic. Despite the mobile devices-enhanced instruction has a rather short history at this institution (only twoyear long pilot process), several researches have been conducted and continuous feedback collected [2]. Consequently, following questions were set to be researched:

1. What types of mobile devices do students possess?

2. What purposes do students use mobile devices for?

3. What is students' feedback after the implementation of mobile devices in English for specific purposes?

\section{THEORETICAL FEEDBACK}

The term of mobile devices to enhance learning (mlearning) has not been precisely defined, i.e. it is understood as:

- learning across multiple contexts, through social and content interactions, using personal electronic devices, concerned with a society on the move, particularly with the education [3];

- a way how the mobility of learners augmented by personal and public technology can contribute to the process of gaining new knowledge, skills and experience [4];

- a digital learning method realized through Intelligent Apparatus equipment [5] which include Palms, Windows CE equipment and digital cellular phone etc.;

- a means able to use the task equipment to acquire knowledge at any time and any place [6].

In this research m-learning, i.e. using mobile devices for educational purposes, is an approach how to reach the same objectives as defined by Comenius didactic principles [7], i.e. purposefulness, clearness, system approach, learners' activity and awareness of intentional activities, retention of knowledge, adequacy, emotionality, and last but not least the joint approval and the consensus of the family. Topically, the ICT-implementation in the process of instruction has become standard; online courses are currently being developed towards MOOC (Massive Open Online Course) and latest technologies, which are of high interest of young people, are being implemented in education so that m-learning was activated. Moreover, as Palalas [8] states if investigating how the mobile technology promotes foreign language learning reflecting didactic principles, the learners' mobility across authentic contexts enables the situated language practice. Mobile-assisted language learning offers learners on-demand flexibility "congruent with learners' increasingly mobile, alwaysconnected lifestyles" [9: 249]. It also enables "continuity 
or spontaneity of access and interaction across different contexts of use" [10:273]. Flexible interaction with teachers, experts and peers offered in a more self-paced collaborative environment can further promote learning. "Additionally, Kukulska-Hulme and Pettit [11] mention convenience and portability, productive utilization of dead time (e.g. when commuting), ability to connect and interact, affordability, accessibility of up-to-date material, and multimedia options. Equipped with a mobile device, the learner can choose to consult a web page, access audio- or video-tutorials, send text message to peers, contact an expert/tutor for guidance etc.

Reflecting all the above mentioned, Marguerite L. Koole [12] designed the FRAME (Framework for the Rational Analysis of Mobile Education) model. It provides answers to questions how a learner can take full advantage of the mobile experience, how study materials and activities appropriate for mobile access should be designed, how mobile learning can be effectively implemented in both the formal and informal learning. The FRAME model offers some insights into these issues as it describes an approach to learning where learners may move within different real and virtual locations and thereby participate and interact with other people, information or systems - anywhere, anytime. The interaction with information is mediated through technology. Within this context, the FRAME model is presented in the form of a Venn diagram in which three aspects (circles) representing the device, learner and social aspects intersect. The device usability and social technology intersections describe the availability (which is called the 'possession' in our research) of mobile technology [13]. The intersection labelled interaction learning contains instructional and learning theories with the emphasis on social constructivism. All three aspects overlap at the primary intersection in the centre of the Venn diagram which defines an ideal mobile learning situation [12]. The FRAME model considers both the technical characteristics of mobile devices and social and personal aspects of learning, thus referring to concepts similar to those found in psychological theories, e.g. in the Activity Theory by Kaptelinin and Nardy [14] and especially pertaining to the work by Vygotsky [15] (on mediation and the zone of proximal development). In the FRAME model, the mobile device is an active component in equal footing to learning and social processes. This model also places more emphasis on constructivism: the word 'rational' refers to the "belief that reason is the primary source of knowledge and that reality is constructed rather than discovered" [16: 15].

To sum up the state, it can be concluded that from elearning, which is widely understood as the immobile ICT-enhanced process of learning, a shift was detected to the exploitation of latest technologies, mainly comprised by mobile devices and relating software. Despite the didactics (pedagogy) of e-learning has defined the theoretical background, m-learning faces the identical process, i.e. basic principles of implementation from the point of both the technology and instruction should be defined and applied. Mobile devices, being very popular within learners of all ages, have a strong impact on the society and education as well, which is the fact that should definitely be taken into consideration, particularly with technical and engineering students who generally have close and warm relationship to the field of technology.

\section{ESP AT FIM IN TECHNICAL AND ENGINEERING EDUCATION}

English for Specific Purposes (ESP) as the most prominent area of English in the foreign language teaching on the higher education level is meeting specific needs of the learners, using methodology and activities of the disciplines it serves. These may differ from those of general English and focus on the language appropriate to these needs in terms of grammar, lexis, learners' skills etc. It may relate to various disciplines, being designed for adult intermediate/advanced learners on tertiary education level or in professional work situation [17]. For technical and engineering students communication in at least two foreign languages is required and defined as a key competence, as mentioned e.g. by Delors [18] and in numerous European Union documents, e.g. [19], [20], [21].

The process of ICT implementation into education started in 1997 at FIM and widely spread after 2000, when the LMS WebCT (Blackboard) exploitation started. Since 2012/13 academic year the virtual desktops have been available to students and teachers, mainly for work with software not providing free/open access (e.g. MS SQL Server, Enterprise Architect). Since 2013/14 the Blackboard Mobile LearnTM, applied in 4.0 version for Apple and Android devices has been piloted (the 4.0 version supports iOS6+, i.e. iPhone 3GS, iPad 2+, IPad mini, iPod Touch 4+ and Android OS 2.3+). This step produced the shift from e-learning to m-learning. In this context, mobile devices are defined as very small items to accompany users anytime and anywhere, autonomous from the electrical supply [22], [23]. Currently, approximately 250 online courses (called e-subjects at FIM) are available to students, either to assist the teaching/learning process, or to be used in the distance form of education. Totally, in 15 of them the mobile-assisted language learning approach was applied - in four courses of English for Specific Purposes (ESP) for IT students, in Business English (four courses), in ESP for Tourism \& Management (two courses), History and Culture: UK (two courses), History and Culture: Australia (one course), History and Culture: New Zealand (one course) and in Academic Writing (one course). All e-subjects run traditionally within the LMS, and currently they are available on mobile devices in the limited extent as well.

The model of MALL for ESP learning applied at FIM blends three types of activities: (1) the face-to-face instruction of full-time students or autonomous learning of part-time students; (2) work in online courses through non-portable devices of both groups, as well as (3) the individualized approach to the online courses through mobile devices. Such a learning model satisfies learners' time/place preferences [24] and bridges formal and informal learning [25]. Under the conditions of FIM, until 2013/14 academic year the ESP was taught for six semesters. Since 2014/15 ESP has been a four-semester compulsory subject taught in the blended (hybrid) way in four online courses (ESP $1-4$ ). Before the first course starts, a face-to-face tutorial is held to show students how the LMS Blackboard works, what services are provided to learners, what study materials are available, in what way assignments are set, submitted and assessed, what tools are available for communication and management of study. Then, 24 hours of face-to-face instruction are held in each semester, organized in two ways: twelve 90-minute lessons per week for full-time students and the same deal of 
independent autonomous study in online courses for parttime students. The process of instruction to be efficient, special didactic means are available to learners to fix and apply the theoretical knowledge in practice: English IT Reader and application for practising vocabulary. Until last academic year both means were available within each online course. Since 2013/14, when mobile devices were widely exploited for education, as displayed in research results presented below, they have been running in the $\mathrm{m}$ learning form as well.

\section{A. English IT Reader}

The English IT Reader was created by students reflecting the Comenius' didactic principle saying that the personal participation and engagement in any activity strengthens motivation and improves study results. In practice, this means students should be given possibility to take active part in acquiring the learning content. In case of part-time learners most of them have enough experience to share with others, and they like to do so. This is contributive from two views: experience of one student can help another one (other ones) and providing own experience boosts professional self-confidence and position within the group.

Reflecting the above mentioned, every year all students of the Faculty of Informatics and Management in the bachelor and master study programmes have been preparing materials for English IT Readers since 2007/8. The Reader is a set of professional texts for education purposes to deepen listening and reading comprehension skills. The work with professional texts is considered useful and it is appreciated by all students because this activity is closely connected to their everyday work and experience, as mentioned above, and they have a wide range of sources they can search professional texts from.

How did the whole process run? Each student prepares two English texts on an IT topic s/he considers interesting and their recordings per one semester. From each text the student selects several important items of professional vocabulary (about $10-15$ items per text) and translates them into Czech language using Insert, Revisions, New Comment tools. The texts and recordings are to meet following requirements:

- The topic of the text relates to the field of study. At the beginning there were four main topics (IT personalities, hardware, software, latest news and products). During the process new topics appeared.

- Length of the text: 3/4 - 1 page of A4 format.

- Language: the level reflects student's knowledge, so texts of different levels are included in the Reader.

- Recordings: the text recordings are provided in mp3 format.

A new edition of the texts and recordings is presented in online courses every year. The content usually covers several topics, e.g. Software, Hardware, Technology, Internet and IT Society etc., but it is not limited to them, any topic of students' interest is welcomed. Students use the Reader to develop their reading comprehension skills, both for everyday communication and prepare and succeed in the final exam after the 4th semester which also includes reading and listening comprehension. Depending on the level of knowledge each student can devote an individual time period to the exam preparation. And, one more thing is motivating: students provide their names under each text so that everybody can know who the au- thor is and evaluate the quality of work. Students carefully protect their professional image and avoid sending texts which do not meet the given requirements.

The Reader is available in online courses, on CDROMs and in the printed versions. Exploiting the Blackboard Mobile LearnTM version 4.0 for Apple and Android devices, the texts and recordings also run on mobile devices (particularly smartphones, tablets, notebooks, netbooks, PDAs). In practice it means students can listen to the texts and read them. Translated vocabulary items are not available within the texts (as they are in online courses) because of the small screen size. But they can be accessed through the second didactic means - the application for practising vocabulary (APV).

\section{B. Application for Practising Vocabulary}

The Application for Practising Vocabulary (APV) contains a database of professional vocabulary to be practised or explained. It works in following steps:

- after clicking the Start button a Czech word appears in the window;

- student types the translation and clicks the Check button;

- Correct or Mistake notice appears;

- in case of Mistake, after re-clicking the Check button the correct answer is displayed;

- either Correct or Mistake notice is displayed, a choice appears whether to remove the item to Learned Words, or to the Try Again group - this means the item remains in the database and is re-displayed later on (if you start the APV again, all items are included in the database);

- in case of Correct answer, after re-clicking the Check button another item appears.

The APV works in the Czech - English or English Czech mode, one item or expression consisting of several words can be included in the database and translated. Moreover, the APV can be also used as glossary - in this case the student writes a word (expression), after clicking the button the explanation appears, either in the Czech Czech or English - English version; or e.g. formulas and relating information can be included in the database.

Both the Reader and APV were originally designed for ESP teaching/learning but they can be exploited in any other foreign language and subject (e.g. as an anthology, glossary etc.).

\section{RESEARCH DESIGN AND Methodology}

As stated in the introductory part, this research deals with three questions, particularly focusing on

- the mobile devices possessed by technical and engineering students at FIM,

- the exploitation of mobile devices in teaching/learning of technical and engineering students at FIM,

- technical and engineering students' feedback after mobile-assisted ESP learning at FIM.

\section{A. Research Sample}

The research was conducted in the sample group of 203 students of the Faculty of Informatics and Management, University of Hradec Kralove

- who enrolled in the bachelor study programme of Informatics $(63 \%)$ and master study programme of Information Management (37\%); 
- having $60 \%$ of male students;

- having $54 \%$ full-time students and $46 \%$ part-time ones;

- being in the age of $19-24$ years $(72 \%), 25$ - 29 years $(13 \%), 30-39$ years $(11 \%)$ and $4 \%$ of $40+$.

\section{B. Methods and Tools}

Data were collected by the method of questionnaire. The questionnaire was available in online courses. It consisted of twelve items focusing on the possession of mobile devices, their use for ESP learning and students' feedback after two semesters of mobile-assisted ESP learning. Respondents provided answers of multiplechoice type questions; four choices were provided in items 1 and 2, all choices could be marked in items $2-8$ and one choice in items $9-12$.

\section{RESEARCH RESULTS}

Data collected by the questionnaire were processed by the method of frequency analysis by the NCSS2007 statistic software and analyzed according to the three above mentioned research questions.

\section{A. Mobile devices respondents possess}

The list of monitored devices contained both the mobile (notebook, netbook, tablet, smartphone, mobile phone, $\mathrm{mp} 3$ player) and immobile ones (PC, game console, TV, DVD player, HI-FI, radio). The collected data are displayed in figure 1 and show notebooks are currently most frequently owned mobile devices ( $88 \%$ of respondents possess them), followed by smartphones (61\%), mobile phones $(52 \%)$, PCs $(52 \%), \mathrm{mp} 3$ players $(49 \%)$, DVD players $(39 \%)$, whereas Hi-fi $(27 \%)$, tablets $(24 \%)$, game consoles $(13 \%)$ and netbooks $(10 \%)$ were rather rarely owned. As expected, students do not have one type of mobile devices only but simultaneous possession of PCs, notebooks, netbooks, tablets, smartphones was proved. Other types of devices were not used so often but respondents also mentioned the ownership of TV $(67 \%)$, radio $(30 \%)$.

\section{B. Purposes students use mobile devices for}

Communication and entertainment were two main purposes which respondents used mobile devices for. The communication was structured into two fields:

- private communication, i.e. with family and friends on related topics,

- professional communication, covering school- and work-related topics.

The third group (entertainment) included gaming and similar, interest-relating activities running on mobile devices). As displayed in figure 2 , notebooks were the most frequently used devices for all three types of activities (approx. $80 \%$ ), followed by smartphones /up to $60 \%$ ), mobile phones and PCs (both around $50 \%$ ). The figure also shows that respondent do not omit personal contact they speak very frequently with the family and friends (96 $\%)$, as well as communicate about school and work matters $(92 \%)$.

When having a detailed view on the school- and workrelated communication in figure 3 , the data are structured into three areas:

- Higher education (HE), i.e. studying at FIM.

- Further education (FE), including interests,

- English for Specific Purposes (ESP).

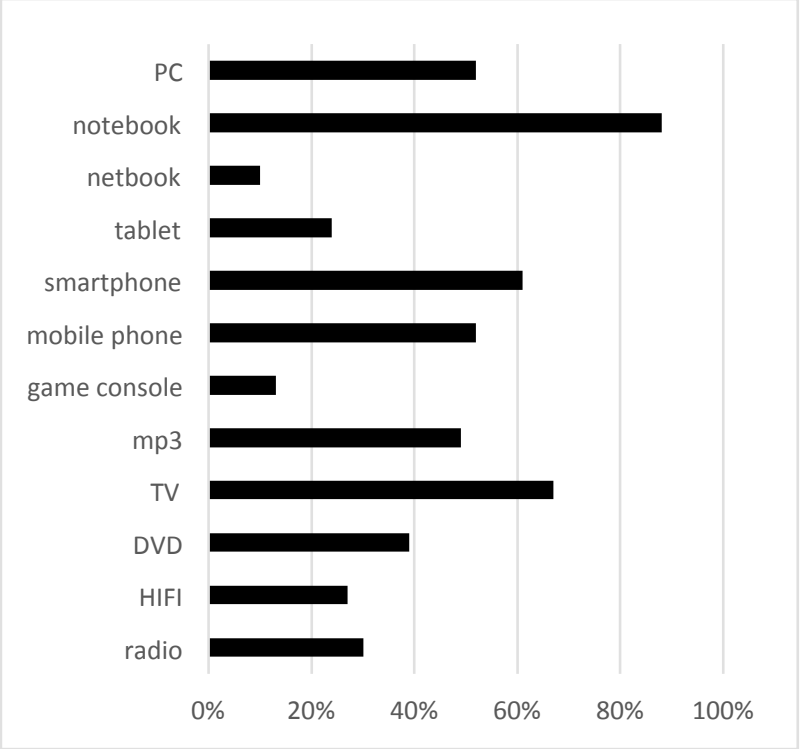

Figure 1. Possession of mobile and other devices (\%)

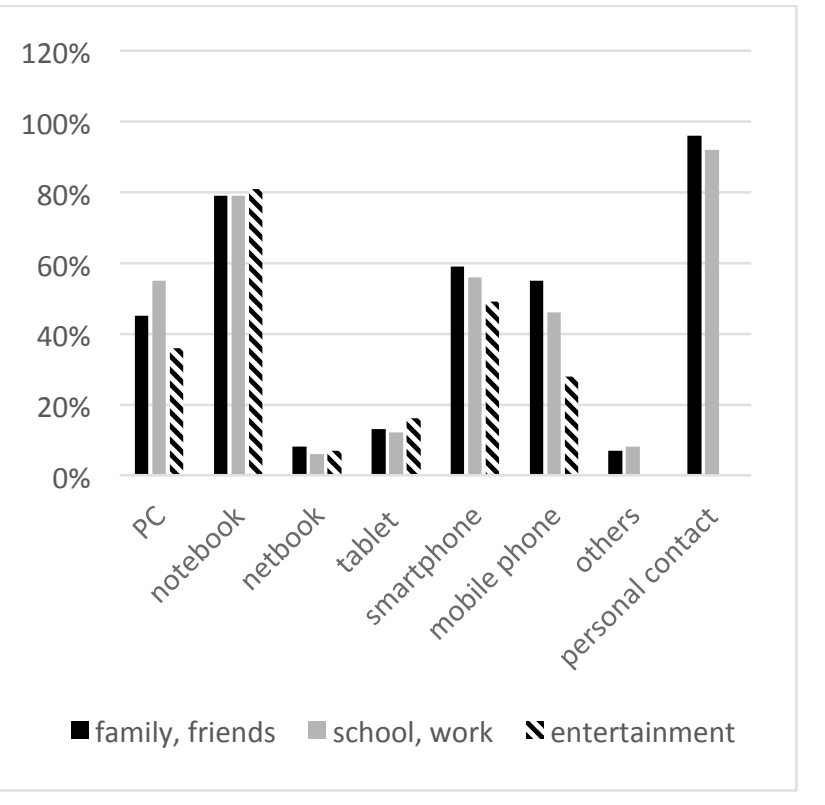

Figure 2. Purposes students exploit mobile devices for

It was not surprising that notebooks were the most frequently exploited device for the higher education, further education and ESP (above $80 \%$ ). Notebooks were followed by PCs (above $40 \%$ ). The most interesting finding was with smartphones for ESP (80\% of respondents exploit smartphones for communication and learning ESP) compared to nearly half-use for other purposes, i.e. higher and further education (around $40 \%$ ). In ESP mobile phones were also used by approx. $30 \%$ of respondents. From other (immobile) devices, TV (42\%) and DVD player $(35 \%)$ were detected - students explained they used them mainly for watching films. Mobile phones and mp3 players are exploited by one third of respondents for ESP learning; other devices are of rather low importance, including tablets $(18 \%)$ and netbooks $(6 \%)$.

Compared to 'other subjects' within university study, the ownership of notebooks was detected with $87 \%$ of respondents, of smartphones with $43 \%$, PC (42\%), mobile phones $(18 \%)$, tablets $(18 \%)$ and netbooks $(7 \%)$. 
Above all, following sources of information were taken into consideration: personal attendance of lectures, I buy books, I borrow books from libraries, e-subjects in LMS, study materials on FIM web page, Wikipedia, materials available from the Internet for free, Facebook, discussion groups, LinkedIn, Google+ other sources. As displayed in figure 4, sources of information respondent's use for ESP show following distribution: e-subjects are obligatorily used by all students $(100 \%)$, as well as the personal attendance of lectures $(96 \%)$ and work with textbooks (both printed and electronic). That is why students borrow textbooks from libraries ( $96 \%$ ), fewer of them buy books (35 $\%$ ), but most of them download study materials from the Internet for free $(92 \%)$. They rather frequently participate in discussion groups within LMS $(81 \%)$ and on Facebook $(95 \%)$, they also often use Wikipedia (72\%), LinkedIn $(24 \%)$; no materials are available on the FIM web page for ESP.

We can sum up, most of them are 'traditional' sources of information which have been applied in e-learning for decades. As mentioned above, what reflects the MALL approach is, the e-subjects run on mobile devices and

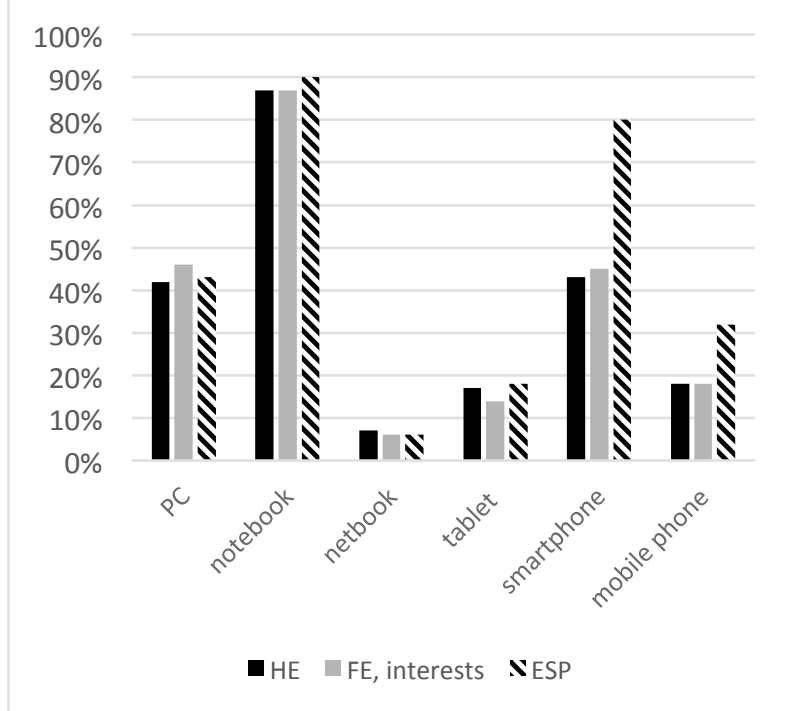

Figure 3. Mobile devices for education.

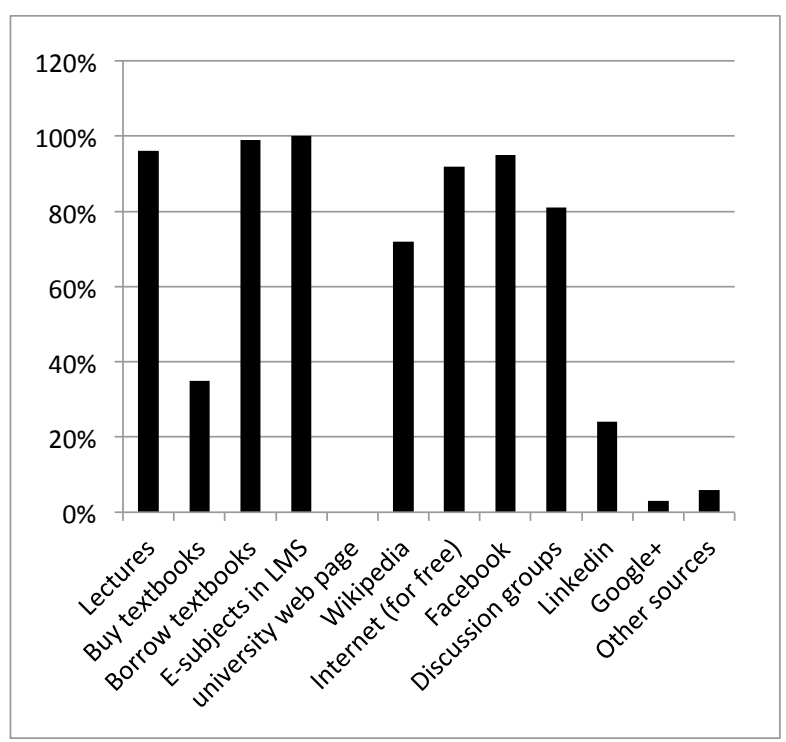

Figure 4. Sources of information exploited for ESP learning social networks (mainly Facebook) are used through mobile devices for sharing experience, study materials, discussing questions etc.

\section{Students'feedback after mobile-assisted ESP Learning compared to othe subjects at FIM)}

After the mobile-assisted ESP process of instruction was closed, respondents provided their experience and opinions. Seven statements drew answers to the question how the use of mobile technology for ESP learning was viewed by individual users on the $1-6$ scale (1: completely agree -6 : completely disagree). The detected results are displayed in table 1 . Most respondents' feedback was highly positive (largely between $1-2$, rather close to 1 ), only several exceptions ( $3 \%$ of respondents) appeared providing lower evaluation. These students had been detected as confluent processors from the point of learning styles and preferences within another research which means they always march to a different drummer, so their attitudes were expected to differ.

Moreover, respondents provided other examples of mobile devices exploitation in calculation applications for Accounting, animations, simulations, modelling for various IT subjects; high quality video-recordings for cultureand history-relating subjects (English, German, Russian, Spanish) etc.

Above all, those who daily commute to school or work by public transport they highly appreciated the possibility to exploit the MALL model.

\section{DISCUSSIONS}

The above presented results collected at FIM reflect those of MALL implementation in the world. In the Czech Republic significant items neither on m-learning, nor MALL have been published. The reason is m-learning has not become as common as e-learning. Long-time data still are not available, as the latest types of mobile devices reached the users later than in economically-strong and developed countries. Currently, the world been global, differences are quickly fading in the field of mobile devices availability. But, the lack of scientifically-verified methodology (didactics) on how to implement mobile de-

TABLE I.

STUDENTS' FEEDBACK AFTER MOBILE-ASSISTED ESP LEARNING

\begin{tabular}{|c|c|c|c|}
\hline \multirow{2}{*}{\multicolumn{2}{|c|}{ Statement }} & \multicolumn{2}{|c|}{ Evaluation coefficient } \\
\hline & & $F \mathrm{CD}$ & Other \\
\hline 1 & $\begin{array}{l}\text { Compared to learning in online courses, I } \\
\text { consider mobile approach anywhere } \\
\text { anytime helpful in the process of ESP } \\
\text { learning. }\end{array}$ & 1.8 & 1.6 \\
\hline 2 & $\begin{array}{l}\text { Compared to learning in online courses, I } \\
\text { consider mobile approach anywhere } \\
\text { anytime significantly helpful in the } \\
\text { process of ESP learning. }\end{array}$ & 2.2 & 2.6 \\
\hline 3 & $\begin{array}{l}\text { I worked with recommended operational } \\
\text { system (OS) and devices (if you did not, } \\
\text { list the OS and devices you used). }\end{array}$ & 1.3 & 1.2 \\
\hline 4 & $\begin{array}{l}\text { I did not have any technical problems (if } \\
\text { you did so, please list them). }\end{array}$ & 1.1 & 1.2 \\
\hline 5 & $\begin{array}{l}\text { The Internet access was as displayed in } \\
\text { Internet signal maps }\end{array}$ & 1.3 & 1.3 \\
\hline 6 & $\begin{array}{l}\text { Would you appreciate using mobile } \\
\text { device in ESP learning in the future? }\end{array}$ & 1.14 & 2.04 \\
\hline
\end{tabular}


evices, particularly how to start the mobile-assisted ESP learning is still missing.

The only valuable result of m-learning implementation (but not MALL) in the Czech Republic was published by Lorenz [26]. He analyzed the concept of mobile education within the changing university environment focusing on the process of learning and the support which libraries can provide. He answers two questions identical to our research and adds two other ones, i.e. whether they students and teachers have sufficient learning/teaching skills to use the potential of m-learning (i.e. students' efficient use of materials and activities designed and implemented in the process of instruction by teachers),

- both groups are sufficiently equipped with mobile devices (podcasts and audio-books are listened by $18 \%$ of students and $12 \%$ of teachers, e-readers are used by $23 \%$ of teachers and $21 \%$ of students, $32 \%$ of students and $23 \%$ of teachers regularly access to social networks, etc.),

- but they feel they have insufficient level of skills for the exploitation of m-learning potential ( $65 \%$ of teachers and $42 \%$ students),

- they are willing/able to cover financial fees for services used,

- their attitudes to m-learning/teaching are positive.

This result contracts to Corbeil and Valdes-Corbeil results where $94 \%$ of students and $60 \%$ of teachers expressed the readiness for using mobile devices for education (from the sample group of 107 students and 30 teachers) [27]. In Lorenz's research totally $57 \%$ of students and $46 \%$ of teachers are willing to pay for services for education purposes and the same amount of both parties would appreciate/are going to implement mobile devices into learning/teaching. All users (teachers and learners) consider mobile devices and technologies useful, easy to use, motivating and enjoyable. These criteria provide strong impact on efficient use of mobile devices and the m-learning in general. No restrictions were detected in this field which would limit this process in MALL.

As mentioned above, this Lorenz's study was carried in 2010, which means data have changed within the fouryear-long period since. This was one of the reasons why our study was important providing latest results reflecting the state in the field. Below, selected world studies are mentioned having close relation to our criteria.

Our study proved identical results as e.g. Viberg, Gronlund [28] who monitored attitudes towards the use of mobile devices in second and foreign language learning in higher education taking cross-cultural view into account. They employed Kearney's pedagogical framework to mobile learning from socio-cultural perspective [29]. The findings showed the positive impact on individualization (83\%), collaboration $(74 \%)$ and authenticity (73\%), whereas gender was identified to be a predictor of differences in students' attitudes to MALL and concluded technology was stronger culture-shaping factor than inherited cultural environment, or age.

Additionally, Hsu [30] investigated the end-users' perception of MALL through cross-cultural analyses in seven countries and regions and discovered that despite significant differences still existed, all respondents agreed MALL to provide potential for EFL learning.

Closely relating to our research topics, in survey by Chen [31] tablets were detected an ideal tool for interac- tive, collaborative and ubiquitous environment for independent informal language learning supported by students' positive attitudes towards their usability, efficiency and satisfaction for the MALL purposes.

In the field of knowledge, de la Fuente [32] focused on the aural input and indicated that learners in the MALL group demonstrated significantly higher levels of reporting noticing, bottom-up comprehension and top-down overall comprehension than learners in instructor manipulated language learning.

On the other hand, Golonka et al. [33] summarized evidence for the effectiveness of technology use in FL learning and teaching, when focusing on studies comparing the use of new technologies (mobile devices, network-based social computing) to traditional methods and immobile devices (PC) and stated limited efficacy of mobile technologies. The strongest impact was discovered in computer-assisted pronunciation training, particularly automatic speech recognition.

Other studies have demonstrated mobile technologies work as helpful and appropriate for language teaching and learning, e.g. Demouy and Kukulska-Hulme [34]. In other studies, significant improvements were detected in listening and reading skills, e.g. Kondo et al. [35] in vocabulary development, e.g. Agca and Ozdemir [36], in learning idioms, e.g. Kargozari and Tafazoli [37], in English vocabulary revision, e.g. Ma, Chen, Hwang, Ding [38], in using task-based approach to design a contextualized MALL, e.g. Tai [39], in pronunciation, e.g. Saran, Seferoglu, Cagiltai [40], etc. Unfortunately, none of these studies provided any complex didactic recommendations applied either within the process of designing single activities/tools, or in the MALL implementation, as it had been done by e.g. Palalas [41], when exploring the design of a Mobile-Enabled Language Learning (MELL) solution she defined a set of ten corresponding design principles and eight technological components which should be integrated into the system.

\section{CONCLUSIONS}

The e-society and i-society produced crucial changes. The process of defining both students' and teachers' key competences towards meeting requirements of today's and future life have been finished, ways to develop and reach them have been set. Putting the whole process into effect is a task we are facing now and in the future. Communication in foreign languages will always belong to key competences, as well as mobile and other types of technologies will be a firm part of our lives. The role of mobile technologies in learning activities and learning contents, difficult financial situation in the field of education in last years, ethical problems relating to the use of mobile devices - these are the hot topics which should be researched and solved in the near future.

\section{REFERENCES}

[1] J. Traxler, "Current state of mobile learning," Mobile learning. Transforming the delivery of education and training. M. Ally (Ed.), pp. 9 - 24, Athabasca University: AU Press, 2009.

[2] I. Šimonová, P. Poulová,, "Cloud and m-learning: longitudinal case study of Faculty of Informatics and Management, University of Hradec Kralove". ACIIDS Bali, 2015, Springer, Berlin.

[3] H. Crompton, "A historical overview of mobile learning: Toward learner-centered education", Z. L. Berge and L. Y. Muilenburg (Eds.), Handbook of mobile learning. Florence, KY: Routledge. 2013. 
[4] M. Sharples, I. A. Sánchez, M. Milrad and G. Vavoula, "Mobile learning: Small devices, Big issues", retrieved April 27, 2014, from http://www.uio.no/studier/emner/matnat/ifi/INF5790/v12/ undervisningsmateriale/ articles/KAL Legacy Mobile Learning (001143v1).pdf

[5] C. Quinn, "M-learning Mobile Wireless" In-Your-PocketLearning $[\mathrm{EB} / \mathrm{OL}]$, retrieved April 30, 2014, from http://www.linezine.com/ 2.1/ features/ cqmmwiyp.htm.

[6] T. Chabra and J. Figueiredo, "How To Design and Deploy Handheld Learning", retrieved April 27, 2014, from http://www.empoweringtechnologies.net/eLearning/eLearning_ex pov5

[7] J. A. Comenius, The Great Didactic [Didactica Magna], Translated into English and edited with biographical, historical and critical introductions by M.W. Keatinge, New York: Russell \& Russell, 1967.

[8] A. Palalas, Design guidelines for a Mobile-Enabled Language Learning system supporting the development of ESP listening skills. 2012a. Doctoral dissertation, Athabasca University. Available from: http://hdl.handle.net/10791/17

[9] (22.9.2014).

[10] A. Kukulska-Hulme and L. Shield, "Editorial", in ReCALL, vol. 20, No. 3, pp.249-252, 2008a.

[11] A. Kukulska-Hulme and L. Shield, "An overview of mobile assisted language learning: From content delivery to supported collaboration and interaction," ReCALL, vol. 20. No. 3, pp. 271289, 2008b. http://dx.doi.org/10.1017/S0958344008000335

[12] A. Kukulska-Hulme and J. Pettit, "Practitioners as innovators: Emergent practice in personal mobile teaching, learning, work and leisure," Mobile learning transforming the delivery of education and training. M. Ally (Ed.), Athabasca University: AU Press, 2009.

[13] M. L. Koole, "A Model for Framing Mobile Learning. In Mobile Learning," Transforming the delivery of education and training. Mobile learning transforming the delivery of education and training. M. Ally (Ed.), pp. 25-48, Athabasca University: AU Press, 2009.

[14] D. Norman, "Affordance, conventions and design," Interactions, vol. 6, No. 3, pp. 38-43, 1999 http://dx.doi.org/10.1145/301 153.301168

[15] V. Kaptelinin and B. Nardi, "Acting with technology: Activity theory and interaction design," Cambridge, MA: MIT Press, 2006.

[16] L. Vygotsky, Mind in society: The development of higher psychological processes. Cole, M., John-Steiner, V., Scribner, S., Souberman, E. (Eds.). Cambridge: Harvard University Press, 1978.

[17] P. Smith and T., "Ragan, Instructional design," 2nd ed. Toronto: John Wiley\&Sons, 1999.

[18] T. Dudley-Evans, "Developments in English for Specific Purposes: A multi-disciplinary approach," Cambridge: Cambridge University Press, 1998.

[19] J. Delors, Task Force on Education for the Twenty-first Century. UNESCO Jaques Delors website Education for the Twenty-first Century. 1999. Retrieved form http://www.unesco.org/delors.

[20] EUROPEAN COMMISSION, Education and Training 2020. Europa. 2009, retrieved 30 January 2013, from http://europa.eu/legislation summaries/education training youth/ general_framework/ef0016_en.htm.

[21] EUROPEAN COMMISSION, The eLearning Action Plan: Designing tomorrow's education. 2001, retrieved 14 December 2014, from http://europa.eu.int/comm/education/elearning/index.html.

[22] EUROPEAN COMMISSION, Towards a Europe of knowledge. Europa. 1997, retrieved January 17, 2014, from http://europa.eu/legislation summaries/other/c11040 en.htm.

[23] J. Roschelle, "Unlocking the learning value of wireless mobile devices", Journal of computer assisted learning, vol. 19, pp. 260272, 2003. http://dx.doi.org/10.1046/j.0266-4909.2003.00028.x

[24] L. Liang, T. Liu, H. Wang, B. Chang, Y. Deng, J. Yang, C. Chou, H. Ko, S. Yang and T. Chan, "A few design perspectives on oneon-one digital classroom environment," Journal of computer assisted learning, vol. 21, No. 3, pp. 181-189, 2005.

[25] M. Pieri and D.Diamantini, "From e-learning to mobile learning: New opportunities," Mobile learning. Transforming the delivery of education and training. M. Ally (Ed.), pp. 183-194, Athabasca University: AU Press, 2009.

[26] M. R. T. L. Abdullah et al. "M-learning scaffolding model for undergraduate English language learning: Bridging formal and informal learning," TOJET: The Turkish online journal of educational technology, vol. 12, No. 2, pp. 217-233, 2013.

[27] M. Lorenz, Kde nechala škola díru: m-learning aneb Vzdělání pro záškoláky [Where school let a hole yawn: m-learning or education for truants]. ProInflow, 2011, 19 p, retrieved from: http://pro.inflow.cz/kde-nechala-skola-diru-m-learning-anebvzdelani-pro-zaskolaky (26.9.2014). ISSN 1804-2406.

[28] J. R. Corbeil and M. E. Valdes-Corbeil, "Are You Ready for Mobile Learning?," Educause Quarterly, vol. 30, No. 2, pp. 51-58, 2007, retrieved from: http://www.educause.edu/ero/article/areyou-ready-mobile-learning (22.9.2014)

[29] O. Viberg and A. Gronlund, "Cross-cultural analysis of users'attitudes towards the use of mobile devices in second and foreign language learning in higher education: A case study from Sweden and China," Computer\&Education, vol. 69, pp. 169-180, 2013 http://dx.doi.org/10.1016/j.compedu.2013.07.014

[30] M. Kearney, S. Schuck, K. Burden and P. Aubusson, "Viewing mobile learning from a pedagogical perspective," Research in Learning Technology, vol. 20, pp. 1-17, 2012. http://dx.doi.org/10.3402/rlt.v20i0.14406

[31] L. W. Hsu, "English as a foreign language learners'perception of mobile assisted language learning: a cross-national study," Computer assisted language learning, vol. 26, No. 3, pp. 197-213, 2013. http://dx.doi.org/10.1080/09588221.2011.649485

[32] X. B. Chen, "Tablets for informal language learning: student usage and attitudes," Language learning\&technology, vol. 17, No. 1, pp. 20-37, 2013.

[33] M. J. de la Fuente, "Learners'attention to input during focus on form listening tasks: the role of mobile technology in the second language classroom," Computer-assisted language learning, vol. 27, No. 3, pp. 261-276, 2014. http://dx.doi.org/10.1080/ $\underline{09588221.2012 .733710}$

[34] E. M. Golonka, A. R. Bowles, V. M. Frank, D. L. Richardson and S. Freynik, "Technologies for foreign language learning," Computer-assisted language learning, vol. 27, No. 1, pp. 70-105, 2014. http://dx.doi.org/10.1080/09588221.2012.700315

[35] V. Demouy and A. Kukulska-Hulme, "On the spot: Using mobile devices for listening and speaking practice on a French language programme," Open Learning: The Journal of Open, Distance and e-Learning, vol. 25, No. 3, pp. 217-232, 2010.

[36] M. Kondo, Y. Ishikawa, C. Smith, K. Sakamoto, H. Shimomura and N. Wada, "Mobile assisted language learning in university EFL courses in Japan: developing attitudes and skills for selfregulated learning," ReCALL, vol. 24, Part 2, pp. 169-187, 2012. http://dx.doi.org/10.1017/S0958344012000055

[37] R. K. Agca and S. Ozdemir, "Foreign language vocabulary learning with mobile technologies," $2^{\text {nd }}$ world conference on educational technology research, vol. 83, pp. 781-785, 2013.

[38] H. R. Kargozari and D.Tafazoli,"Idiom on the move," INTED 2012: $6^{\text {th }}$ international conference on technology, education and development, INTED Proceedings, pp. 3866-3869, 2012.

[39] Z. H. Ma, S. Y. Chen, W. Y. Hwang and W. J. Ding, "Digital game-based after-school-assisted learning system in English," IEEE international symposium on intelligent signal processing and communications systems, pp. 130-135, 2012. http://dx.doi.org/10.1109/ispacs.2012.6473466

[40] Y. M. Tai, "Contextualizing a MALL: practice design and evaluation," Educational technology\&society, vol. 15, No. 2, pp. 220230, 2012.

[41] M. Saran, G. Seferoglu and K. Cagiltai, "Mobile assisted language learning: English pronunciation at learners'fingertips," Egitim arastirmalari-eurasian journal of education research, vol. 8, No. 34, pp. 97-114, 2009.

[42] A. Palalas, "Mobile-Enabled Language Learning Eco-System," Specht, M., Sharples, M., Multisilta, J. (Eds.), Proceedings of the $11^{\text {th }}$ international conference on mobile and contextual learning, pp. 1-8, 2012b. 


\section{AUTHOR}

Ivana Simonova has been with the University of Hradec Kralove, Faculty of Informatics and Management, Department of Applied Linguistics since 1997, teaching English for Specific Purposes for bachelor degree students of Applied Informatics and engineering (master) degree students of Information Management (e-mail: ivana.simonova@uhk.cz).

This paper is supported by the SPEV 2016 project. This article is an extended and modified version of a paper presented at the International Conference on Interactive Collaborative Learning (ICL2015), held 20-24 December 2015, in Florence, Italy. Manuscript received 22 January 2016. Published as resubmitted by the authors 09 March 2016. 